\title{
The Right to Public Education, Democracy, and Social Struggles
}

This issue entitled The right to public education, democracy, and social struggles, brings into debate key problems of public education in Brazil. We are, as will be seen in the articles, at a critical moment where we may lose everything we had achieved. Those are tough concerns, not just because the authors chose challenging topics to deal with in their articles. They are tough because of the nature of the materiality in which we are historically entangled, a situation that the researchers generously collaborate to expose. The line of thoughts supporting the studies concern the social function of public schools - from the primary to the superior education - and the derisive character of official policies they are subjected to. Most articles examine Brazilian social policies, including educational ones, from after the 1990s. Although dissenting, the researchers attribute to the economic and political orientations derived from the neoliberal project implemented in Brazil from the governments of President Fernando Henrique Cardoso (1995-2002) to President Michel Temer (August 2016-2018), the responsibility for ongoing counter-reforms in social policies, particularly those on education.

The reader is shown various areas that stifle Brazilian schooling: low quality basic education; the precarious education of youth at the middle and higher levels; teacher preparation from a pragmatic perspective; the largely precarious work teachers are submitted to; projects that aim to 'silence' the school; the funding cuts as consequence of education plans and regressive laws. There are many strategies to destroy the public-school in the country. The authors, backed by careful empirical research and theoretical reflection, seek to dismantle these strategies and offer the readers, a crystalline field of perception, exposing the crucial role played by the state and the private apparatus of hegemony present in civil society. We emphasize the authors reference to the work of Marx and authors of Marxist tradition - Gramsci, Mészáros, Fernandes, Lukács, Marini, Bambirra, Löwy, Mariátegui, among others. There is a laudable effort not to abstract the educational sphere of its more general determinations, namely the capitalist relations of production and reproduction of human existence and its perverse consequences on work and schooling.

Of the eleven thematic publications, three are directly related to the right to education in democracy and the role of the state. In the article Political and economic disputes over Brazilian educational democratization in the 21 st century, Carlos Felipe Nunes Moreira reflects on the high school counter-reform, focused on meeting the demands of the business sectors and limited to a "focal policy." To adapt youth intellectual education to the labor market and depoliticize both students and teachers, the current project poses limits to the secondary education. Moreira understands that without organized struggle it is not possible to break with bourgeois hegemony and that its agenda should contain school democratization in several aspects: the guarantee of access and permanence; quality of education; pedagogical changes. The author believes the field of Social Work has an important contribution, both in terms of denouncing the conditions that capitalism imposes on young people and their social rights, and in overcoming the capitalist order.

As for the questions around democracy, the article by Doracy Dias Aguiar de Carvalho and Roberto Francisco de Carvalho, Democracy and social rights: history and implications for Brazilian educational policies, points out that the concept of democracy faces permanent disputes in capitalism due to the clash

(C) The Author(s). 2019 Open Access This article is distributed under the terms of the Creative Commons Attribution-NonCommercial 4.0 International License (http://creativecommons.org/licenses/by-nc/4.0/), which permits use, distribution, and reproduction in any medium, since it's for non-commercial purposes, and provided you give appropriate credit to the original author(s) and the source, provide a link to the Creative Commons license, and indicate if changes were made. 
between socially antagonistic classes. Representative, liberal democracy and substantive, socialist democracy conform to different conceptions of society and social rights. In the post-1990 conjuncture, the state and the imperialism, financed the dismantling of working class rights, particularly regarding education. The de-politicization referred to by Moreira reappears as a phenomenon in civil society, which the liberal democracy understands as a sphere free of litigation (although this litigation is the element that materializes civil society). Struggles for the preservation of hard-won rights, and even formally granted rights, are fundamental. These rights are targeted by bourgeoisie and can be destroyed or turned into commodities. Despite the regressive framework and its current complexification, the national-popular educational project, articulated with the construction of socialist democracy, is on the agenda. New sociability must be established, in which human emancipation is the horizon of the relations between economy and politics.

The article by Mônica Regina Nascimento dos Santos Correio, State, education, and human rights, points out that issues related to human rights - such as the innumerable forms of violation of the rights of individuals - are a contemporary problem connected to liberal heritage. The author states that after 1848 the idea of human rights supplanted revolutionary utopia; on the other hand, this utopia has given way to practices linked to human rights as protection of the individual's right, detached from their class. Without losing sight of these determinations, the author points out that the struggle for human rights has kept important achievements, albeit minimal and often restricted to some groups. A theoretical literature review highlights two strands of analysis: one that criticizes the limits that such protection entails and another that considers it possible to insert this protection in a counter-hegemonic perspective of human rights. The article describes the fact that, in the context of educational policies and the state, we are living the quest for the consolidation of human rights that supposed to be granted in the 21 st century.

Next, this issue presents five articles on the formal aspects of implementing the right to education at all levels, including the national system and national education plans. The article The Brazilian basic education in dispute: indoctrination vs neutrality, by Ana Claudia Rodrigues de Oliveira, Fabio Lanza, and Letícia Jovelina Storto recovers the history of the movement School without Party (ESP) from 2004 when it was founded by Miguel Nagib and turned in a bill in process in several Brazilian states and municipalities. In the documents collected and examined based on the critical analysis of discourse, there was a strong presence of the notions of "ideological indoctrination" and "neutrality of teaching" with disastrous repercussions on the social function of the school and the concepts of knowledge and education, among others. However, the ESP proposes the curtailment of teaching practice, as well as the control of the sociology teaching in high school, admitting, in the case of the city of São Paulo, only the positivist and scienticist sociological knowledge whose ultimate objective is to reproduce the current project of society. This perspective directly affects the teachers' work and preparation, which historically suffer attempts to be controlled as it is considered a threat. Un-intellectualizing students and teachers is part of the hegemonic political project to contain proposals that question capitalist society.

Education and labor in Brazil: workers' education in the perspective of the capital by Jaime Hillesheim and Adir Valdemar Garcia examines the President Cardoso government's National Education Plan (2001-2011), the Education Development Plan (2007) of President Lula da Silva government, and President Dilma Rousseff's National Education Plan (2014-2024). In agreement with other articles in this issue, the authors consider that we are living a process of losing rights, a result of the capitalist crisis that worsened enormously after 2008; Our peripheral and dependent economy is rapidly advancing in widening social inequality. They draw attention to the fact that the right to public school is subordinated to market interests. In vocational and technical education, in youth and adult education, in high school or higher education, young people are trained under the slogans of employability, entrepreneurship, autonomy, competitiveness. This situation puts the relationship between work and education under scrutiny and brings to light the objective and subjective ways of subordinating workers to the interests of production and reproduction of capitalist society. When analyzing educational policies between 2003 and 2015, the article focuses on this relationship, concluding that workers' education is linked to the bourgeois sociability frameworks underlying the "exercise of citizenship." One important contribution is the demonstration that we are facing the centrality of schooling as a mediator of the preparation of work for capital.

Benedito de Jesus Pinheiro Ferreira's article Public education as a social right: challenges for the construction of a coordinated system in Brazil, analyzes education as a social right and public good, fundamental for human emancipation, presenting the literature produced in the historical-critical pedagogical framework, whose author par excellence is Dermeval Saviani. On the one hand, it discusses the more general determinations of the Brazilian public school, among which the problem of public financing; on the other, the objective possibilities of an emancipatory educational praxis. For the author, three aspects need to be considered: the need for a national education system; the obstacles arising from public education underfunding; and the hegemony of bourgeois pedagogies, as in the so fashionable "learning to learn." These three aspects undermine the social function of the school: enabling the active appropriation of scientific knowledge historically produced by humanity. 
From this point of view, the defense of public education, social right, an inescapable part of the emancipatory project, is on the agenda. Therefore, it is necessary to produce objective knowledge about education so that its contradictory relationship with peripheral capitalism are clarified and can support a social project of human emancipation, for which the collective struggle is fundamental.

Although the bourgeoisie does not consider university or higher education an inherent right to forming the human, Kátia Regina de Souza Lima, in the article Higher education in times of neoliberal adjustment and loss of rights, and Mailiz Garibotti Lusa, Tiago Martinelli, Samara Ayres Moraes, and Tiago Pacheco Almeida, in the article The public university in times of neoliberal adjustment and loss of rights, adopt this perspective. Lima opens a provocative debate about what she called "phases of neoliberal counterrevolution": the one concerning the governments by Presidents da Lula da Silva and Rousseff (2003-2016), whose mark was the conciliation of classes; and President Temer's government (2016-2018), which deepens economic inequalities and takes away workers' rights. The public policies triggered during this period - "fiscal adjustment, interest payments and public debt repayments, and attacks on social rights" - reached higher education and the state triggered violent processes for its exponential privatization. For the author, we are facing "a new stage of the class struggle in the country." Lusa, Martinelli, Moraes, and Almeida agree with Lima's conclusion and state that higher education has historically been the object of dispute between distinct political projects. The actors in the struggle arena are those committed to a transformative project of education, and those who support the neoliberal offensive and loss of rights. The authors consider it possible to strengthen the resistance to bourgeois hegemony, being the public university an essential player, since it is a space of intervention for professors, researchers, and students committed to this transformative project, whether in teaching, research, or extension. The dismantling of public education in Brazil, particularly in the President Bolsonaro's government, is ongoing and can be understood as a response to the capital demand for worker training. However, this is an issue that goes back to the 1990s. The governments of the post-1990 governments triggered this kind of response to the structural crisis of capital. Thus, attacking public universities and echoing the guidelines of international organizations are part of this response and theuniversities' privatization is on the horizon, although the majority of enrollment in Brazil is already in the private sector.

Closing this discussion, the issue presents two themes generically named as the "school floor," as a reference to the shop floor in factories. Fábio Machado Pinto and Lara Beatriz Fuck, in their article Coping with 'Medicalizing Knowledge' and School Practices in Florianópolis, discuss how medicalizing generates consequences for school work fulfilling the ideological function of obscuring the social inequalities present in the institution. The authors point out that difficulties that students present to perform activities or to connect with the school knowledge can be considered "mental and psychological disorders." This diagnosis results in drug treatment, precisely configuring the "medicalization process" with consequences on school performance. The authors cite the case of the state of Santa Catarina that occupied the sixth place in the consumption of Ritalin between 2009 and 2014. After a literature review in the area of Sociology of Education regarding the theme and educational and health policies, associated with an empirical study, the authors discuss the concept of medicalization based on Sartrean references. There is a growing interest in the subject, and it is possible to observe a predominance of multidisciplinary and critical approaches in the literature. The authors conclude by stating that, from a perspective based on historical-cultural psychology, it is possible to understand the pathologizing and biologizing bases of such practices and seek their overcoming in public schools.

Rosângela Araújo Darwich and Maria Lúcia Dias Gaspar Garcia, in the article Experiential groups and staying in school: securing rights, discuss the relationship between non-coercive experiential groups and the possibility of developing social skills among public high school students. The authors seek to offer answers to the challenge of personal and relational transformation articulated to the need for permanence in school. The authors show that social skills are connected to social competency, among which they account for "assertiveness", "empathy," and "problem-solving," generically understood as "emotional and interpersonal development." The authors argue that actions based on trust and respect generate civility, citizenship, and democracy, securing the right to education. Contrary to other authors, they claim it is necessary to believe in the quality of relationships that are established both at school and socially, guided by the need to build social skills.

The final article in the issue is on educational possibilities beyond schooling. In Latin America in the twentieth century: revolutions, muralism, imperialism, and dependency, Roberta Sperandio Traspadini asks: "What does Mexican muralism have to teach us in the 21st century?". Bringing together modern Mexican muralists David Siqueiros, Diego Rivera, and Clemente Orozco to a theoretical approach grounded in the Marxist theory of dependency, it explores the educational potential of murals regarding political struggles in Latin America and the Caribbean. The author demonstrates how the political engagement of image, music, and poetry was in the 1960s and 1970s - and remains - vital for political education in popular socialist movements while emphasizing the strategies of capitalist hegemony to contain it. The article cites, for example, the 
"memoricide, genocide, and ethnocide" derived not only from the colonial invasion but from the numerous dictatorial and authoritarian processes that have occurred in the region throughout history. On the other hand, it proposes a debate about the use of public spaces, of the city, as supports for the critique of social relations of capitalist production. Murals or graffiti show critical reflection on imperialism in Latin America and the Caribbean and the means to overcome it.

This issue is lavish with complex topics to encourage discussion. The spectrum of problems regarding Brazilian social policies addressed (particularly on Public Education) is central and must be understood within an expanded context. I reaffirm that those are tough concerns and topics because, among other reasons, there is a profound alienation overcoming the ability of the majority to understand where the economic determinations of the last 40 years have fallen. The government of President Bolsonaro has been marked by the loss of working-class rights, the dismantling of social policies, the criminalization of social movements, the attack on the environment, and the destruction of public school at all levels. Thousands took to the streets, in the first half of 2019, in defense of public education and social security, among other simultaneous political demands and movements in the national territory. It is not undeniable the subaltern capitalist relations of production in which we live, immersed in the imperialist barbarism. However, despite the toughness evidenced in the articles published in this issue, the researchers point to the possibilities of overcoming this situation. They show that the contradictions of our peripheral and dependent capitalism carry alternative social projects; that there are opportunities for the working class to find solutions; that music, poetry, image, space, time, organization, and revolutionary theory are available. It is necessary, however, to engage in this struggle.

Olinda Evangelista, Florianópolis, August 26, 2019.

\section{Olinda Evangelista}

http://orcid.org/0000-0001-5360-2521

olindaevangelista35@hotmail.com

$\mathrm{PhD}$ in Education from the Pontifical Catholic University of São Paulo (PUC-SP). Senior Professor at the University of West Santa Catarina (UNOESC) and Retired Volunteer Professor at the Graduate Education Program at the Federal University of Santa Catarina (UFSC).

\section{UFSC}

Programa de Pós-Graduação em Educação

Campus Universitário Reitor João David Ferreira Lima, Centro de Ciências da Educação - Trindade

Florianópolis - Santa Catarina - Brasil

CEP: 88.040-900 